J. Amer. Soc. Hort. ScI. 115(2):212-218. 1990.

\title{
Growth and Productivity of Vigorous 'Northern Spy'/MM.106 Apple Trees in Response to Annually Applied Growth Control Techniques
}

\author{
D.C. Elfving ${ }^{1}$ \\ Horticultural Research Institute of Ontario, Box 587 Simcoe, Ont. N3Y 4N5, Canada \\ R.A. Cline ${ }^{1}$ \\ Horticultural Research Institute of Ontario, Vineland Station, Ont. LOR 2EO, Canada \\ Additional index words. daminozide, ethephon, summer pruning, Malus domestics
}

Abstract. Beginning in 1982, daminozide (DZ) was applied annually for 5 years to whole, 5-year-old 'Northern Spy'/ MM.106 (Malus domestics Borkh.) trees: a) shortly after bloom, b) together with ethephon (ETH) 6 to 7 weeks after bloom, or c) after harvest. Controls were unsprayed. One-half of the trees receiving each growth regulator treatment were summer-pruned after terminal-bud formation each year. Postharvest DZ reduced shoot numbers, mean shoot length, trunk enlargement, and fruit size, but had little or no effect on bloom, fruit set, or yield. Postbloom DZ, summer DZ plus ETH, and summer-pruning reduced vegetative growth and time required for dormant-pruning, but only postbloom DZ and summer DZ plus ETH increased spur density in the tree. Postbloom DZ and summer DZ plus ETH increased both flowering and cropping in 3 of the 5 years, with little effect on fruit set. Fruit size was reduced only in years when cropping was enhanced. Total yields (1982-86) were increased 34\% and 36\% by postbloom DZ and summer DZ plus ETH, respectively. Summer-pruning had no effect on fruit size in any year, but reduced yields in 1984 and 1986. Year-to-year fluctuation in yield was unaffected by any treatment. Growth-control treatments had no direct effect on foliar or fruit macronutrient concentrations. Chemical names used: butanedioic acid mono (2,2-dimethylhydrazide) (daminozide); 2-chloroethylphosphonic acid (ethephon).

The 'Northern Spy' apple is grown in Ontario mainly for processing, but also for the fresh market (Proctor, 1979a). Despite continued demand, new plantings have steadily declined over the past 30 years (Ontario Min. of Agr. and Food, 1987) because of its vigorous vegetative growth, especially in dense plantings, and lack of precocity (Preston, 1978; Proctor, 1979b).

Growth regulators and summer-pruning can restrict vegetative growth and increase productivity of apple trees (Marini and Barden, 1987; Mika, 1986; Miller, 1988; Saure, 1987). Daminozide or ETH applied shortly after bloom reduces shoot growth and may or may not increase flowering the next year (Batjer et al., 1964; Edgerton and Greenhalgh, 1969; Fisher and Looney, 1967; Forshey, 1970; Forshey and Edgerton, 1974; Jones et al., 1988; Looney, 1969; Veinbrants, 1972; Williams, 1972). However, ETH applied postbloom at concentrations required to control shoot growth and induce flowering produces severe crop loss in fruiting trees (Edgerton and Greenhalgh, 1969; Forshey and Edgerton, 1974; Lord et al., 1975; Williams, 1972). Ethephon applications after June drop increase return bloom with little effect on fruit set (Lord et al., 1975; Williams, 1972). Combinations of DZ plus ETH applied after June drop increase

Received for publication 2 June 1989. Mention of a product or trade name does not constitute a guarantee or warranty of the product by the Hort. Res. Inst. of Ontario nor an endorsement over similar products not mentioned. The cost of publishing this paper was defrayed in part by the payment of page charges. Under postal regulations, this paper therefore must be hereby marked advertisement solely to indicate this fact.

${ }^{1}$ Research Scientist. flowering at lower concentrations of each material (Greene et al., 1977b; Jaumien, 1983; Lord et al., 1975; Williams, 1972).

Daminozide applied at any time during the growing season can reduce fruit size that year and/or the following year as a carryover effect (Batjer et al., 1964; Fisher and Looney, 1967; Forshey, 1970; Greene et al., 1986; Jones et al., 1988; Looney, 1969; Looney et al., 1967; Lord, 1971; Oldham and Greenhalgh, 1968; Southwick et al., 1968, 1973). Postbloom DZ applications may or may not improve fruit set and may have little effect on yield (Forshey, 1970; Greene et al., 1977a, 1977b; Luckwill and Silva, 1979; Southwick et al., 1973). Carryover effects from fall-applied DZ can increase fruit set to a greater extent than postbloom treatments (Greene et al., 1986; Sullivan and Widmoyer, 1970).

Increased vegetative growth has been observed the year after DZ was applied for growth control (Greene and Lord, 1978; Schumacher, 1973; Tromp, 1972), sometimes with no increase in yield (Greene and Lord, 1978). Williams (1973) suggested that repeated applications over several years might be necessary to maintain adequate flowering and fruiting in vigorous trees.

Few studies have examined the effects of repeated growthregulator treatments over several years. Annual or biennial applications of DZ postbloom starting in the 2 nd or 4 th year after planting increased cumulative yield over 7 to 9 years by up to $60 \%$ (Schumacher et al., 1986). Other studies of up to 10 years' duration showed from $\mathrm{O} \%$ to $38 \%$ increase in total production from annual DZ and/or ETH applications (Edgerton and Lisk, 1974; Grauslund, 1975, 1976; Greene and Lord, 1983; Lord, 1971; Mika et al., 1983). 
Summer-pruning can reduce vegetative growth in apple (Alderman and Auchter, 1916; Greene and Lord, 1983; Marini and Barden, 1982; Myers and Ferree, 1983; Preston and Perring, 1974; Utermark, 1977) and has been used to restrict tree height and spread in vigorous trees (Mika et al., 1983; Myers and Ferree, 1983). Summer-pruning increases (Emerson and Hayden, 1981; Marini and Barden, 1982a), has no effect on, or decreases yield (Bardenand Marini, 1984; Dozier et a1., 1982; Greene and Lord, 1983; Marini and Barden, 1982). Annual summer-pruning in August reduced trunk enlargement over 5 years, but had little effect on shoot growth or cropping (Barden and Marini, 1984). Combining postbloom DZ with summerpruning helped control shoot growth and improve fruit set in vigorous 'Cortland' trees (Greene and Lord, 1983).

The objective of this trial was to examine the long-term effects of three annually applied growth-regulator strategies on growth and cropping of vigorous, young 'Northern Spy' trees experiencing crowded conditions in a dense planting. These strategies, each tested alone or in combination with summerpruning, were: 1) control of vigorous shoot growth with DZ shortly after bloom; 2) induction of flowering while minimizing crop loss with DZ plus ETH applied after June drop; or 3) stimulation of fruit set with DZ applied after harvest.

\section{Materials and Methods}

Treatments were initiated in 1982 on 'Northern Spy'/MM.1O6 trees planted in 1977 at a spacing of $3.0 \times 4.9 \mathrm{~m}$ (673 trees/ ha). Their canopies had already begun to overlap at the time the trial began. Four growth-regulator treatments were combined in a factorial arrangement with or without summer pruning (eight treatment combinations). Each treatment combination was applied annually to single, whole-tree plots in a randomized complete-block design with 10 replications. The growth-regulator treatments were as follows: a) postbloom DZ (1500 $\mathrm{mg} \cdot$ liter $^{-1}$, sprayed to runoff with a handgun when terminal extension shoots were 10 to $15 \mathrm{~cm}$ long (2 June 1982; 7 June 1983; 2 June 1984; 22 May 1985; 22 May 1986; an average of 9.8 days after bloom). In 1984, $1000 \mathrm{mg} \cdot$ liter $^{-1} \mathrm{DZ}$ was used; c) summer DZ (1500 mg.liter ${ }^{-1}$ ) plus ETH (250 mg.liter ${ }^{-1}$, sprayed to runoff as a tank mix with a handgun after the completion of June drop (5 July 1982; 7 July 1983; 9 July 1984; 26 June 1985; 1 July 1986; an average of 44.8 days after bloom); d) postharvest DZ (2000 mg.liter $\left.{ }^{-1}\right)$ sprayed to runoff with a handgun following harvest (19 Oct. 1982; 26 Oct. 1983; 24 Oct. 1984). This treatment was discontinued after 1984.

Summer-pruning was carried out annually after terminal bud formation when no regrowth was expected (18 Aug. 1982; 10 Aug. 1983; 20 Aug. 1984; 16 Aug. 1985; 1 Aug. 1986). Summer-pruning was limited to removal of vigorous current-season shoots by thinning cuts to weak laterals. Very few heading cuts were made, and very little older wood was removed.

All trees were pruned each April before budbreak to contain them within their allocated spaces; to preferentially remove vigorous, upright, dead, or otherwise undesirable wood; and to maintain an open canopy. Dormant-pruning emphasized thinning cuts, with heading cuts kept to the absolute minimum. Fertilization and pest-control practices were carried out each year in accordance with local recommendations.

Total blossom clusters, fruit set after June drop, and shoot growth after summer-pruning were determined annually on a single sample limb per tree selected each spring (Forshey and Elfving, 1979). Limb circumference was measured at a predetermined location at bloom and again when shoot growth was measured in late August. Trunk circumference was recorded on each tree each year following leaf drop at a pre-marked location $30 \mathrm{~cm}$ above the soil surface.

The time required to complete dormant-pruning for each whole tree was recorded each year, beginning in 1983. Total time required to summer-prune the entire trial was also recorded each year. In 1986, time needed for summer-pruning was recorded for each summer-pruned tree in the trial. Shoots were separated into length classes when measured each year. In 1987, the number of spurs was counted on each test limb when shoot growth was measured. Growth-regulator treatments were applied in 1987 on the same schedule as in previous years, but summer-pruning was discontinued after 1986. Yield was determined annually by counting all fruit on each tree at harvest and weighing the fruit. Bienniality was assessed on yields for 1982-83, 1983-84, 198485 and 1985-86 using the $i$ index of Hoblyn et al. (1936), and these values were also combined into an overall mean bienniality index for the 5 years.

Midshoot leaves from current-season shoot growth were collected each August and processed for foliar analysis according to the methods of Bodnar et al. (1983). Fruit samples were collected at harvest in 1984 and 1986, subsampled, and wetashed at 550C for similar analyses.

All data were evaluated using analysis of variance (ANOVA) and means separated by ANOVA or Duncan's multiple range test using the General Linear Models (GLM) procedure of the Statistical Analysis System (SAS) program package (SAS Institute, Cary, N.C. ). Fruit-set data were transformed using the arcsin of the square root before analysis.

\section{Results}

Vegetative growth. Among growth regulators, only postharvest DZ decreased both shoot number and mean length relative to the control; this effect disappeared by the 2 nd year after the treatment was terminated (Table 1). Summer-pruning reduced shoot numbers each year. Both postbloom DZ and summer DZ plus ETH reduced mean shoot length, but the effect of summer DZ plus ETH began in 1983. Summer-pruning reduced mean shoot length in all but one season (Table 1) due to the preferential removal of longer shoots (data not shown).

Dormant-pruning time was reduced significantly by any treatment that decreased mean shoot length the previous season, regardless of its effect on shoot number (Table 2). Summerpruning decreased dormant-pruning time to a much greater extent than any growth regulator treatment alone. Among growth regulator treatments in 1986, only postbloom DZ reduced summer-pruning time.

Postbloom DZ and summer DZ plus ETH increased the number of spurs per centimeter of limb circumference, even though the total number of growing points was unchanged (Table 3 ). Summer-pruning through 1986 reduced spur density, but did not influence total growing points per centimeter of limb circumference in 1987. Postharvest DZ, although only applied through 1984, reduced the number of spurs and total growing points per centimeter of limb circumference in 1987.

Postbloom application of DZ reduced trunk cross-sectional area (TCSA) growth in 3 of the 5 years of this study and DZ plus ETH reduced it in each of the 5 years (Table 4). By the end of the trial, DZ plus ETH reduced final TCSA to a greater extent than postbloom DZ. Summer-pruning significantly decreased annual TCSA increment in 3 of the 5 years of the trial. These effects were small, however, and, at the end of the trial, 
Table 1. Effects of growth control treatments on annual shoot growth of 'Northern Spy' apple trees. ${ }^{2}$

\begin{tabular}{|c|c|c|c|c|c|c|c|c|c|c|}
\hline \multirow[b]{2}{*}{ Treatment } & \multicolumn{5}{|c|}{$\begin{array}{l}\text { No. shoots } / \mathrm{cm} \text { limb } \\
\text { circumference }\end{array}$} & \multicolumn{5}{|c|}{ Mean shoot length $(\mathrm{cm})$} \\
\hline & 1982 & 1983 & 1984 & 1985 & 1986 & 1982 & 1983 & 1984 & 1985 & 1986 \\
\hline Control & $3.3 \mathrm{a}$ & $3.8 \mathrm{a}$ & $5.2 \mathrm{a}$ & $5.1 \mathrm{~b}$ & $5.5 \mathrm{a}$ & $27 \mathrm{a}$ & $26 \mathrm{a}$ & $26 \mathrm{a}$ & $24 \mathrm{a}$ & $24 \mathrm{a}$ \\
\hline \multicolumn{11}{|l|}{ Growth regulators $\left(\mathrm{mg} \cdot \mathrm{liter}^{-1}\right)^{\mathrm{y}}$} \\
\hline DZ 1500 postbloom & $3.6 \mathrm{a}$ & $4.3 \mathrm{a}$ & $5.2 \mathrm{a}$ & $5.2 \mathrm{ab}$ & $5.7 \mathrm{a}$ & $18 \mathrm{~b}$ & $15 \mathrm{c}$ & $21 \mathrm{~b}$ & $16 \mathrm{c}$ & $15 \mathrm{c}$ \\
\hline DZ $1500+$ ETH 250 summer & $3.9 \mathrm{a}$ & $4.4 \mathrm{a}$ & $5.2 \mathrm{a}$ & $5.9 \mathrm{a}$ & $5.3 \mathrm{a}$ & $26 \mathrm{a}$ & $17 \mathrm{c}$ & $22 \mathrm{~b}$ & $20 \mathrm{~b}$ & $20 \mathrm{~b}$ \\
\hline DZ 2000 postharvest & $3.5 \mathrm{a}$ & $3.2 \mathrm{~b}$ & $4.0 \mathrm{~b}$ & $4.2 \mathrm{c}$ & $5.2 \mathrm{a}$ & $28 \mathrm{a}$ & $23 \mathrm{~b}$ & $22 \mathrm{~b}$ & $21 \mathrm{~b}$ & $24 \mathrm{a}$ \\
\hline \multicolumn{11}{|l|}{ Summer-pruning ${ }^{x}$} \\
\hline Control & $4.2 \mathrm{a}$ & $4.3 \mathrm{a}$ & $5.6 \mathrm{a}$ & $5.8 \mathrm{a}$ & $6.3 \mathrm{a}$ & $26 \mathrm{a}$ & $20 \mathrm{a}$ & $24 \mathrm{a}$ & $23 \mathrm{a}$ & $23 \mathrm{a}$ \\
\hline Summer-pruned & $3.0 \mathrm{~b}$ & $3.5 \mathrm{~b}$ & $4.2 \mathrm{~b}$ & $4.4 \mathrm{~b}$ & $4.6 \mathrm{~b}$ & $24 \mathrm{~b}$ & $20 \mathrm{a}$ & $21 \mathrm{~b}$ & $18 \mathrm{~b}$ & $18 \mathrm{~b}$ \\
\hline
\end{tabular}

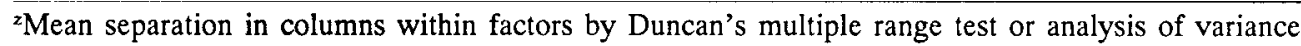
$(P=0.05)$.

'Each value is the mean of 20 observations.

*Each value is the mean of 40 observations.

Table 2. Effect of growth control treatments on 'Northern Spy' apple trees on annual dormant pruning time in each of 5 years and summer pruning time in $1986^{\mathrm{z}}$.

\begin{tabular}{|c|c|c|c|c|c|c|c|}
\hline \multirow[b]{2}{*}{ Treatment } & \multicolumn{6}{|c|}{ Dormant pruning time/tree $(\mathrm{min})^{\mathrm{y}}$} & \multirow{2}{*}{$\begin{array}{c}\text { Summer pruning } \\
\text { time/tree } \\
\text { (1986) (min) }\end{array}$} \\
\hline & 1983 & 1984 & 1985 & 1986 & 1987 & Total & \\
\hline $\begin{array}{l}\text { Control } \\
\text { Growth regulators }\left(\mathrm{mg} \cdot \operatorname{liter}^{-1}\right)\end{array}$ & $2.7 \mathrm{a}$ & $5.1 \mathrm{a}$ & $7.5 \mathrm{a}$ & $6.9 \mathrm{a}$ & $8.9 \mathrm{a}$ & $31.1 \mathrm{a}$ & $9.4 \mathrm{a}$ \\
\hline $\begin{array}{l}\text { DZ } 1500 \text { postbloom } \\
\text { DZ } 1500+\text { ETH } 250\end{array}$ & $2.1 \mathrm{~b}$ & $3.6 \mathrm{c}$ & $6.0 \mathrm{~b}$ & $4.3 c$ & $5.0 \mathrm{~b}$ & $21.0 \mathrm{c}$ & $5.5 b$ \\
\hline summer & $2.7 \mathrm{a}$ & $4.2 \mathrm{~b}$ & $6.3 \mathrm{~b}$ & $5.5 \mathrm{~b}$ & $6.0 \mathrm{~b}$ & $24.7 \mathrm{bc}$ & $9.4 \mathrm{a}$ \\
\hline $\begin{array}{l}\text { DZ } 2000 \text { postharvest } \\
\text { Summer-pruning }\end{array}$ & $3.2 \mathrm{a}$ & $4.4 \mathrm{~b}$ & $5.8 \mathrm{~b}$ & $5.2 \mathrm{bc}$ & $7.9 \mathrm{a}$ & $26.5 \mathrm{~b}$ & $9.9 \mathrm{a}$ \\
\hline $\begin{array}{l}\text { Control } \\
\text { Summer-pruned }\end{array}$ & $\begin{array}{l}3.3 \mathrm{a} \\
2.1 \mathrm{~b}\end{array}$ & $\begin{array}{l}5.0 \mathrm{a} \\
3.7 \mathrm{~b}\end{array}$ & $\begin{array}{l}7.9 \mathrm{a} \\
4.9 \mathrm{~b}\end{array}$ & $\begin{array}{l}7.6 \mathrm{a} \\
3.3 \mathrm{~b}\end{array}$ & $\begin{array}{l}9.7 \mathrm{a} \\
4.2 \mathrm{~b}\end{array}$ & $\begin{array}{l}33.5 \mathrm{a} \\
18.1 \mathrm{~b}\end{array}$ & -- \\
\hline
\end{tabular}

${ }^{z}$ Mean separation in columns within factors by Duncan's multiple range test or analysis of variance $(P=0.05)$.

yEach value is the mean of 20 observations.

"Each value is the mean of 10 observations.

"Each value is the mean of 40 observations.

Table 3. Effect of growth control treatments on density of spurs and total growing points of 'Northern Spy' apple trees'.

\begin{tabular}{|c|c|c|}
\hline \multirow[b]{2}{*}{ Treatment } & \multicolumn{2}{|c|}{$\begin{array}{c}\text { No./cm limb circumference } \\
(1987)\end{array}$} \\
\hline & Spurs & Total growing points ${ }^{x}$ \\
\hline Control & $5.2 \mathrm{~b}$ & $10.6 \mathrm{a}$ \\
\hline \multicolumn{3}{|l|}{ Growth regulators $\left(\mathrm{mg} \cdot \mathrm{liter}^{-1}\right)^{y}$} \\
\hline DZ 1500 postbloom & $5.9 \mathrm{a}$ & $11.3 \mathrm{a}$ \\
\hline DZ $1500+$ ETH 250 summer & $6.0 \mathrm{a}$ & $11.2 \mathrm{a}$ \\
\hline DZ 2000 postharvest & $4.5 \mathrm{c}$ & $9.1 \mathrm{~b}$ \\
\hline \multicolumn{3}{|l|}{ Summer-pruning ${ }^{\mathrm{w}}$} \\
\hline Control & $5.5 \mathrm{a}$ & $10.3 \mathrm{a}$ \\
\hline Summer-pruned & $5.3 \mathrm{~b}$ & $10.8 \mathrm{a}$ \\
\hline
\end{tabular}

${ }^{z}$ Mean separation in columns within factors by Duncan's multiple range test or analysis of variance $(P=0.05)$.

yEach value is the mean of 20 observations.

Total number of shoots plus spurs.

"Each value is the mean of 40 observations.

TCSA of summer-pruned trees was $94 \%$ of those not summerpruned.

Growth control treatments had little effect on foliar or fruit macronutrient concentrations (data not shown). Foliar $\mathrm{K}$ con- centration was reduced by treatments that significantly increased yield. No macronutrient deficiencies or excesses were observed.

Productivity. Flowering was increased by postbloom DZ or summer DZ plus ETH in 3 out of 5 years where there was potential for an effect (Table 5). Postharvest DZ did not influence bloom and summer-pruning effects varied among years. Fruit set was not consistently affected by growth regulator treatments, while summer-pruning reduced fruit set only in 1986.

Yield was increased by postbloom DZ and summer DZ plus ETH in 3 of the 5 years, producing a significant increase in cumulative yield as well (Table 6). Postharvest DZ did not influence yield throughout the trial. Summer-pruning decreased yield in 1984, likely related to the reduced bloom that year, and in 1986, probably as a result of poorer fruit set. Although there was no statistically detectable effect of summer-pruning on yield in the other years, annual summer-pruning decreased cumulative yield over 5 years.

Fruit weight was decreased by postbloom DZ or summer DZ plus ETH only in years when yields were significantly greater than for the control (Table 7). In contrast, while postharvest DZ had no effect on yield, it decreased fruit weight to a greater extent each year following its application than did either postbloom DZ or summer DZ plus ETH. Summer-pruning had no effect on fruit size during this study. 
Table 4. Effect of growth control treatments on annual trunk cross-sectional area (TCSA) growth of 'Northern Spy' apple trees.

\begin{tabular}{|c|c|c|c|c|c|c|c|}
\hline \multirow[b]{2}{*}{ Treatment } & \multirow{2}{*}{$\begin{array}{c}\text { Initial TCSA } \\
\left(\mathrm{cm}^{2}\right)\end{array}$} & \multicolumn{5}{|c|}{ Annual TCSA increment $\left(\mathrm{cm}^{2}\right)$} & \multirow{2}{*}{$\begin{array}{c}\text { Final TCSA } \\
\left(\mathrm{cm}^{2}\right)\end{array}$} \\
\hline & & 1982 & 1983 & 1984 & 1985 & 1986 & \\
\hline Control & $38.0 \mathrm{a}$ & $11.8 \mathrm{ab}$ & $19.4 \mathrm{a}$ & $21.6 \mathrm{a}$ & $21.1 \mathrm{a}$ & $21.4 \mathrm{a}$ & $133.2 \mathrm{a}$ \\
\hline \multicolumn{8}{|l|}{ Growth regulators $\left(\mathrm{mg} \cdot \operatorname{liter}^{-1}\right)^{\mathrm{y}}$} \\
\hline DZ 1500 postbloom & $38.0 \mathrm{a}$ & $10.6 \mathrm{~b}$ & $15.1 \mathrm{~b}$ & $22.1 \mathrm{a}$ & $18.0 \mathrm{ab}$ & $17.2 \mathrm{~b}$ & $121.0 \mathrm{~b}$ \\
\hline DZ $1500+$ ETH 250 summer & $36.9 \mathrm{a}$ & $10.5 b$ & $14.8 \mathrm{~b}$ & $17.1 \mathrm{~b}$ & $14.4 \mathrm{c}$ & $13.9 \mathrm{~b}$ & $107.6 \mathrm{c}$ \\
\hline DZ 2000 postharvest & $36.2 \mathrm{a}$ & $14.4 \mathrm{a}$ & $17.8 \mathrm{a}$ & $20.3 \mathrm{a}$ & $17.2 \mathrm{bc}$ & $20.7 \mathrm{a}$ & $126.6 \mathrm{ab}$ \\
\hline \multicolumn{8}{|l|}{ Summer-pruning $x$} \\
\hline Control & $37.3 \mathrm{a}$ & $11.7 \mathrm{a}$ & $17.8 \mathrm{a}$ & $20.9 \mathrm{a}$ & $18.7 \mathrm{a}$ & $19.5 \mathrm{a}$ & $125.9 \mathrm{a}$ \\
\hline Summer-pruned & $37.3 \mathrm{a}$ & $11.9 \mathrm{a}$ & $15.7 \mathrm{~b}$ & $19.6 \mathrm{a}$ & $16.6 \mathrm{~b}$ & $17.2 \mathrm{~b}$ & $118.3 \mathrm{~b}$ \\
\hline
\end{tabular}

${ }^{z}$ Mean separation in columns within factors by Duncan's multiple range test or analysis of variance $(P=0.05)$.

yEach value is the mean of 20 observations.

${ }^{x}$ Each value is the mean of 40 observations.

Table 5. Effect of growth control treatments on annual bloom and fruit set of 'Northern Spy' apple trees'.

\begin{tabular}{|c|c|c|c|c|c|c|c|c|c|c|c|}
\hline \multirow[t]{2}{*}{ Treatment } & \multicolumn{6}{|c|}{ Blossom clusters $/ \mathrm{cm}$ limb cirumference } & \multicolumn{5}{|c|}{ Fruit set/100 blossom clusters } \\
\hline & 1982 & 1983 & 1984 & 1985 & 1986 & 1987 & 1982 & 1983 & 1984 & 1985 & 1986 \\
\hline $\begin{array}{l}\text { Control } \\
\text { Growth regulators }\left(\mathrm{mg} \cdot \mathrm{liter}^{-1}\right)^{\mathrm{y}}\end{array}$ & $1.0 \mathrm{a}$ & $1.6 \mathrm{~b}$ & $1.0 \mathrm{a}$ & $2.4 \mathrm{~b}$ & $3.3 \mathrm{~b}$ & $2.5 \mathrm{~b}$ & $253 a$ & $152 \mathrm{c}$ & $160 \mathrm{a}$ & $149 \mathrm{ab}$ & $98 \mathrm{ab}$ \\
\hline $\begin{array}{l}\text { DZ } 1500 \text { postbloom } \\
\text { DZ } 1500+\text { ETH } 250 \text { summer } \\
\text { DZ } 2000 \text { postharvest }\end{array}$ & $\begin{array}{l}1.1 \mathrm{a} \\
1.0 \mathrm{a} \\
0.9 \mathrm{a}\end{array}$ & $\begin{array}{l}2.7 \mathrm{a} \\
2.4 \mathrm{a} \\
1.5 \mathrm{~b}\end{array}$ & $\begin{array}{l}1.4 \mathrm{a} \\
1.2 \mathrm{a} \\
1.1 \mathrm{a}\end{array}$ & $\begin{array}{l}3.6 \mathrm{ab} \\
4.6 \mathrm{a} \\
3.4 \mathrm{ab}\end{array}$ & $\begin{array}{l}5.8 \mathrm{a} \\
3.8 \mathrm{ab} \\
2.5 \mathrm{~b}\end{array}$ & $\begin{array}{l}5.6 \mathrm{a} \\
4.8 \mathrm{a} \\
4.1 \mathrm{ab}\end{array}$ & $\begin{array}{l}186 \mathrm{a} \\
212 \mathrm{a} \\
326 \mathrm{a}\end{array}$ & $\begin{array}{l}194 \mathrm{bc} \\
205 \mathrm{ab} \\
249 \mathrm{a}\end{array}$ & $\begin{array}{l}198 \mathrm{a} \\
184 \mathrm{a} \\
252 \mathrm{a}\end{array}$ & $\begin{array}{l}112 \mathrm{~b} \\
138 \mathrm{ab} \\
162 \mathrm{a}\end{array}$ & $\begin{array}{r}81 \mathrm{~b} \\
113 \mathrm{a} \\
51 \mathrm{c}\end{array}$ \\
\hline ning $x$ & & & & & & & & & & & \\
\hline $\begin{array}{l}\text { Control } \\
\text { Summer-pruned }\end{array}$ & $\begin{array}{l}1.1 \mathrm{a} \\
0.9 \mathrm{a}\end{array}$ & $\begin{array}{l}1.9 \mathrm{a} \\
2.2 \mathrm{a}\end{array}$ & $\begin{array}{l}1.4 \mathrm{a} \\
0.9 \mathrm{~b}\end{array}$ & $\begin{array}{l}3.0 \mathrm{~b} \\
4.0 \mathrm{a}\end{array}$ & $\begin{array}{l}4.3 \mathrm{a} \\
3.3 \mathrm{a}\end{array}$ & $\begin{array}{l}3.5 \mathrm{~b} \\
5.0 \mathrm{a}\end{array}$ & $\begin{array}{l}204 \mathrm{a} \\
284 \mathrm{a}\end{array}$ & $\begin{array}{l}200 \mathrm{a} \\
197 \mathrm{a}\end{array}$ & $\begin{array}{l}210 \mathrm{a} \\
185 \mathrm{a}\end{array}$ & $\begin{array}{l}146 \mathrm{a} \\
131 \mathrm{a}\end{array}$ & $\begin{array}{r}100 \mathrm{a} \\
70 \mathrm{~b}\end{array}$ \\
\hline
\end{tabular}

${ }^{2}$ Mean separation in columns within factors by Duncan's multiple range test or analysis of variance $(P=0.05)$.

'Each value is the mean of 20 observations.

Table 6. Effect of growth control treatments on annual and cumulative yield of 'Northern Spy' apples (1982-1986) ${ }^{2}$.

\begin{tabular}{lcccccc}
\hline \hline & \multicolumn{4}{c}{ Annual yield (kg/tree) } & \multicolumn{2}{c}{$\begin{array}{c}\text { Cumulative } \\
\text { yield } \\
\text { Treatment }\end{array}$} \\
\cline { 2 - 6 }$(\mathrm{kg} /$ tree $)$
\end{tabular}

${ }^{2}$ Mean separation in columns within factors by Duncan's multiple range test or analysis of variance $(P=0.05)$.

'Each value is the mean of 20 observations.

${ }^{x}$ Each value is the mean of 40 observations.

'Northern Spy' tends to produce in a biennial pattern. Neither growth regulators nor summer-pruning materially influenced the natural alternation of cropping in this trial.

\section{Discussion}

Annual summer-pruning effects did not interact with the growth regulators and only marginally decreased overall tree growth and cropping. Summer-pruning decreased the annual dormantpruning requirement to the greatest extent. Nonetheless, summer-pruned trees required a greater total pruning time (Elfving, 1988).
While the postbloom DZ and summer DZ plus ETH treatments were expected to influence growth control and cropping differently, their effects on tree structure and productivity were virtually identical. Both treatments increased the number of spurs at the expense of shoots. Over 5 years, cumulative yields for these two treatments were $\approx 35 \%$ greater than for the control. In contrast, postharvest DZ reduced shoot and spur numbers, but had no effect on yield.

Postbloom DZ and summer DZ plus ETH reduced fruit weight only in those years in which cropping was increased. The carryover effects of postharvest DZ reduced fruit size each year without increasing yield. The absence of fruit-size reductions 
Table 7. Effect of growth control treatments on annual mean fruit weight and overall bienniality index of 'Northern Spy' apple trees.'

\begin{tabular}{|c|c|c|c|c|c|c|}
\hline \multirow[b]{2}{*}{ Treatment } & \multicolumn{5}{|c|}{ Mean fruit wt (g) } & \multirow{2}{*}{$\begin{array}{l}\text { Mean bienniality } \\
\text { index } 1982-86 \\
(i * 100)\end{array}$} \\
\hline & 1982 & 1983 & 1984 & 1985 & 1986 & \\
\hline Control & $200 \mathrm{a}$ & $190 \mathrm{a}$ & $190 \mathrm{a}$ & $230 \mathrm{a}$ & $230 \mathrm{a}$ & $46 \mathrm{ab}$ \\
\hline \multicolumn{7}{|l|}{ Growth regulators $\left(\mathrm{mg} \cdot \operatorname{liter}^{-1}\right)^{y}$} \\
\hline $\begin{array}{l}\text { DZ } 1500 \text { postbloom } \\
\text { DZ } 1500+\text { ETH } 250\end{array}$ & $190 \mathrm{a}$ & $160 \mathrm{c}$ & $180 \mathrm{a}$ & $200 \mathrm{~b}$ & $180 \mathrm{~b}$ & $44 a b$ \\
\hline summer & $180 \mathrm{a}$ & $150 \mathrm{~d}$ & $180 \mathrm{a}$ & $180 \mathrm{c}$ & $180 \mathrm{~b}$ & $38 \mathrm{~b}$ \\
\hline DZ 2000 postharvest & $200 \mathrm{a}$ & $170 \mathrm{~b}$ & $140 \mathrm{~b}$ & $170 \mathrm{~d}$ & $230 \mathrm{a}$ & $56 \mathrm{a}$ \\
\hline \multicolumn{7}{|l|}{ Summer-pruning $x$} \\
\hline Control & $190 \mathrm{a}$ & $170 \mathrm{a}$ & $180 \mathrm{a}$ & $200 \mathrm{a}$ & $210 \mathrm{a}$ & $45 \mathrm{a}$ \\
\hline Summer-pruned & 190 a & $160 \mathrm{a}$ & $170 \mathrm{a}$ & 190 a & $210 \mathrm{a}$ & $47 \mathrm{a}$ \\
\hline
\end{tabular}

from postbloom DZ or summer DZ plus ETH when yields were similar to those of the controls suggests no direct or carryover effects from these treatments on fruit development. This result is at variance with observations on other cultivars, especially from postbloom DZ sprays (Fisher and Looney, 1967; Forshey, 1970; Greene et al., 1986; Jones et al., 1988; Looney, 1969; Looney et al., 1967; Lord, 1971; Oldham and Greenhalgh, 1968; Southwick et al., 1968, 1973).

Fruit set was increased by summer DZ plus ETH and postharvest DZ in 1983 and decreased by postharvest DZ in 1986. Postharvest DZ failed to increase fruit set, except in 1983, even though shoot growth was reduced both in number and mean length for 3 years while the carryover effect of this treatment was present. Delayed bloom, associated with DZ carryover and reported to influence fruit-set response in some studies (Greene et al., 1986; Sullivan and Widmoyer, 1970), was not observed in this trial.

Shoot elongation was reduced each year by postbloom DZ and by DZ plus ETH starting in 1983 (2nd year of the trial). Since DZ plus ETH was applied each year near the time of terminal-bud formation, the effect of this treatment on shoot growth could only result from a reduction in vegetative vigor of the tree or from carryover effects. Since none of the other carryover effects produced by postharvest $\mathrm{DZ}$ were observed for the DZ plus ETH treatment, it seems unlikely that DZ carryover could explain its effect on shoot growth. Daminozide plus ETH increased flowering in 1983, with no significant effect on shoot growth in 1982. While a negative correlation between shoot growth and subsequent flowering has been reported frequently (Greene and Lord, 1978; Jones et al., 1989; Walsh and Kender, 1982), induction of flower formation with growth regulators without reducing shoot growth is not unusual (Luckwill, 1970; Tromp, 1972; Volz and Knight, 1986).

The effects of growth regulators and summer-pruning reported here appear to have little to do with mineral nutrition. Both leaf and fruit samples indicated little effect of any treatment on matron.utrient levels.

Trunk cross-sectional area growth over the 5-year trial period was reduced by both postbloom DZ and summer DZ plus ETH. Since TCSA growth is inversely related to fruiting (Forshey, 1989), both postbloom DZ and summer DZ plus ETH apparently shifted the vegetative-fruiting relationship in favor of cropping by increasing spur density in the canopy, and possibly by a direct effect on flowering as well. Reduced dormant-pruning times as well as reduced shoot length from the DZ plus ETH treatment, even in years when cropping was not different from controls, support this hypothesis. Ethephon may have contributed directly to the greater reduction in TCSA growth for the summer DZ plus ETH treatment relative to postbloom DZ. In contrast, summer-pruning produced a dwarfing effect from the greater total annual pruning these trees received, without a shift between vegetative and reproductive growth. There is no evidence in this trial to indicate an effect of any growth regulator or summer-pruning directly on the physiological processes of dry-weight allocation (Forshey and Elfving, 1989).

The tendency of 'Northern Spy' to crop in a partially biennial pattern was largely uninfluenced by growth-control techniques, whether applied separately or together. These results also support the concept that those treatments that produced increases in yield (postbloom DZ and summer DZ plus ETH) simply shifted the trees toward a more productive condition without altering internal mechanisms governing year-to-year fluctuations in production.

Annual postbloom DZ and summer DZ plus ETH treatments had beneficial and almost identical effects on growth, productivity, and estimated economic return (Elfving, 1988). Postharvest DZ produced only detrimental effects and was eliminated as a viable strategy by 1985 . As practiced in this trial, summerpruning reduced dormant-pruning, but did not replace it. Because of that fact and the absence of any beneficial effect on yield, summer-pruning proved ineffective for controlling vegetative growth and/or stimulating cropping.

\section{Literature Cited}

Alderman, W.H. and E.C. Auchter. 1916. The apple as affected by varying degrees of dormant and seasonal pruning. W.Va. Expt. Sta. Bul. 158 .

Barden, J.A. and R.P. Marini. 1984. Summer and dormant pruning of apple - a four-year summary, Acts Hort. 146:263-268.

Batjer, L. P., M.W. Williams, and G.C. Martin. 1964. Effects of Ndimethyl amino succinamic acid (B-nine) on vegetative and fruit characteristics of apples, pears and sweet cherries. Proc. Amer. Soc. Hort. Sci. 85:11-16.

Bodnar, J. M., J.T.A. Proctor, J.E. Laing, and R.A. Cline. 1983. Nutrient changes in apple leaves due to the spotted tentiform leafminer. J. Amer. Soc. Hort. Sci. 108:681-685.

Dozier, W. A., Jr., C.C. Carleton, and K.C. Swart. 1982. Effects of 
mechanical and hand pruning, tree spacing, and limb bending on tree development and yield of hedgerow 'Delicious' apples on Malling Merton 106 rootstock. J. Amer. Soc. Hort. Sci. 107:295-298.

Edgerton, L.J. and W.J. Greenhalgh. 1969. Regulation of growth, flowering and fruit abscission with 2-chloroethanephosphonic acid. J. Amer. Soc. Hort. Sci. 94:11-13.

Edgerton, L.J. and D.J. Lisk. 1974. Some effects of applying SADH annually for 10 years on three apple cultivars. Proc. XIX Intl. Hort. Congr. 1A:431.

Elfving, D.C. 1988. Economic effects of excessive vegetative growth in deciduous fruit trees. HortScience 24:461-463.

Emerson, F.H. and R.A. Hayden. 1981. The effect of training and pruning systems on the long-term yields of apple. Compact Fruit Tree 14:80-87.

Fisher, D.V. and N.E. Looney. 1967. Growth, fruiting and storage response of five cultivars of bearing apple trees to N-dimethylaminosuccinamic acid (Alar). Proc. Amer. Soc. Hort. Sci. 90:9-19.

Forshey, C.G. 1970. The use of Alar on vigorous 'McIntosh' apple trees. J. Amer. Soc. Hort. Sci. 95:64-67.

Forshey, C.G. 1989. Measuring the effects of growth regulators on the vegetative growth-fruiting relationship in apple trees. Acts Hort. 239:211-219.

Forshey, C.G. and L.J. Edgerton. 1974. The use of ethephon on apples. N.Y. State Agr. Expt. Sta. Info. Bul. 57.

Forshey, C.G. and D.C. Elfving. 1979. Branch samples for yield and fruit size comparisons in apple. HortScience 14:143-144.

Forshey, C.G. and D.C. Elfving. 1989. The relationship between vegetative growth and fruiting in apple trees, p. 229-287. In: J. Janick (cd.). Horticultural reviews. vol. 11. Timber Press, Portland, Ore.

Grauslund, J. 1975. Vaekstregulatorer til frugttraeer. II. Markforsog med SADH til unge aeble- og paeretraeer. Tidsskr. for Planteavl 79:37-50.

Grauslund, J. 1976. Vaekstregulatorer til frugttraeer. IV. Virkningen af SADH til aeblesorten 'Cortland'. Tidsskr. for Planteavl 80:391399.

Greene, D,W. and W.J. Lord. 1978. Evaluation of scoring, limb spreading and growth regulators for increasing flower bud initiation and fruit set on young 'Delicious' apple trees. J. Amer. Soc. Hort. Sci. 103:208-210.

Greene, D.W. and W.J. Lord. 1983. Effects of dormant pruning, summer pruning, scoring, and growth regulators on growth, yield, and fruit quality of 'Delicious' and 'Cortland' apple trees. J. Amer. Soc. Hort. Sci. 108:590-595.

Greene, D. W., W. J. Lord, and W. J. Bramlage. 1977a. Mid-summer applications of ethephon and daminozide on apples: I. Effect on 'McIntosh'. J. Amer. Soc. Hort. Sci. 102:491-494.

Greene, D. W., W. J. Lord, and W. J. Bramlage. 1977b. Mid-summer applications of ethephon and daminozide on apples: II. Effect on 'Delicious'. J. Amer. Soc. Hort. Sci. 102:494-497.

Greene, D. W., W.J. Lord, F. W. Southwick, and J. E. Sincuk. 1986. Effects of postharvest and postbloom sprays of daminozideon apples. Fruit Var. J. 40:41-45.

Hoblyn, T. N., N.H. Grubb, A.C. Painter, and B.L. Wates. 1936. Studies in biennial bearing. I. J. Pomol. and Hort. Sci. 14:39-76.

Jaumien, F. 1983. Effect of SADH and CEPA on elongation growth and anatomical structure of apple stem. Acta Hort. 137:135-143.

Jones, K. M., P. Jotic, T.B. Koen, S.B. Longley, and G. Adams. 1988. Restructuring and cropping large 'Red Delicious' apple trees with paclobutrazol and daminozide. J. Hort. Sci. 63:19-25.

Jones, K. M., T.B. Keen, S. Wilson, M. Oakford, and S.B. Longley. 1989. Are-examination of the relationship between vegetative growth and flower bud initiation in apples. Acts Hort. 239:363-366.

Looney, N.E. 1969. Importance of time and concentration of annual applications of succinic acid 2,2-dimethyl hydrazide (Alar) to pome fruits. Can. J. Plant Sci. 49:495-198.

Looney, N. E., D. V. Fisher, and J. E. W. Parsons. 1967. Some effects of annual applications of N-dimethylaminosuccinamic acid (Alar) to apples. Proc. Amer. Soc. Hort. Sci. 91:18-24.

Lord, W.J. 1971. Effects of annual sprays of succinic acid 2,2-di- methyl hydrazide on vegetative growth, fruiting, fruit quality and pre-harvest drop of 'Delicious' apple trees. J. Amer. Soc. Hort. Sci. 96:687-690.

Lord, W. J., D.W. Greene, and R. A. Damon, Jr. 1975. Evaluation of fruit abscission and flower bud promotion capabilities of ethephon and SADH on apples. J. Amer. Soc. Hort. Sci. 100:259-261.

Luckwill, L.C. 1970. The control of growth and fruitfulness of apple trees, p. 237-254. In: L.C. Luckwill and C.V. Cutting (eds.). Physiologyof tree crops. Academic, New York.

Luckwill, L.C. and J.M. SiIva. 1979. The effect of daminozide and gibberellic acid on flower initiation, growth and fruiting of apple CV. Golden Delicious. J. Hort. Sci. 54:217-223.

Marini, R.P. and J.A. Barden. 1982. Growth and flowering of vigorous apple trees as affected by summer or dormant pruning. J. Amer. Soc. Hort. Sci. 107:34-39.

Marini, R.P. and J.A. Barden. 1987. Summer pruning of apple and peach trees. Hort. Rev. 9:351-375.

Mika, A. 1986. Physiological responses of fruit trees to pruning. Hort. Rev. 8:337-378.

Mika, A., M.J. Grochowska, A. Karaszewska, and M.W. Williams. 1983. Effects of dormant and summer pruning, disbudding, and growth retardants on growth, flower bud formation, and fruiting of young apple trees. J. Amer. Soc. Hort. Sci. 108:655-660.

Miller, S.S. 1988. Use of plant bioregulators in apple and pear culture. Hort. Rev. 10:309-401.

Myers, S.C. and D.C. Ferree. 1983. Influence of time of summer pruning and limb orientation on growth and flowering of vigorous 'Delicious' apple trees. J. Amer. Soc. Hort. Sci. 108:634-638.

Oldham, M.A. and W.J. Greenhalgh. 1968. The effect of Alar on vegetative growth and fruiting behaviour of three varieties in the central tablelands of New South Wales. Austral. J. Expt. Agr. Anim. Hush. 8:450-455.

Ontario Min. of Agr. and Food. 1987. Fruit tree census 1986. Part III. Apples. Plant Industry Branch. Toronto.

Preston, A.P. 1978. Growth and cropping of two slow-bearing apples on two very vigorous rootstock. Hort. Res. 18:137-139.

Preston, A.P. and M.A. Perring. 1974. The effect of summer pruning and nitrogen on growth, cropping and storage quality of Cox's Orange Pippin apple. J. Hort. Sci. 49:77-83.

Proctor, J.T.A. 1979a. Apple cultivars grown in Canada. Fruit Var. J. 33:12-15.

Proctor, J.T.A. 1979b. The growth and cropping of the slow-bearing 'Northern Spy' apple on the two vigorous rootstock M.25 and M.16. Hort. Res. 19:75-78.

Saure, M. 1987. Summer pruning effects in apple-a review. Scientia Hort. 30:253-282.

Schumacher, R. 1973. The influence of growth regulators on shoot and root development of fruit trees. Acts Hort. 34:175-183.

Schumacher, R., F. Fankhauser, and W. Stadler. 1986. Influence of growth regulators, ringing and root cutting on apple quality and physiological disorders. Acts Hort. 179:731-742.

Southwick, F. W., W.J. Lord, and W.D. Weeks. 1968. The influence of succinamic acid 2,2-dimethylhydrazide (Alar) on the growth, productivity, mineral nutrition, and quality of apples. Proc. Amer. Soc. Hort. Sci. 92:71-81.

Southwick, F.W., W.J. Lord, D.W. Greene, and L.G. Cromack. 1973. Residual effects of summer applications of succinic acid 2,2-dimethylhydrazide on 'McIntosh' apple trees. J. Amer. Soc. Hort. Sci. 98:593-595.

Sullivan, D.T. and F.B. Widmoyer. 1970. Effects of succinic acid 2,2dimethylhydrazide (Alar) on bloom delay and fruit development of Delicious apples. HortScience 5:91-92.

Tromp, J. 1972. Effects of growth-regulating substances and tree orientation on growth and flower-bud formation in apple. J. Hort. Sci. 47:525-533.

Utermark, H. 1977. Summer pruning to control growth and maintain fruiting in mature apple trees. Compact Fruit Tree 10:86-90.

Veinbrants, N. 1972. Effects of succinic acid 2,2-dimethyl hydrazide 
(Alar) or scoring on growth and flower initiation of young apple trees. Austral. J. Expt. Agr. Anim. Hush. 12:89-95.

Volz, R.K. and J.N. Knight. 1986. The use of growth regulators to increase precocity in apple trees. J. Hort. Sci. 61: 181-189.

Walsh, C.S. and W.J. Kender. 1982. Effect of cultivar, strain, and growth regulator treatments on shoot development and ethylene evolution in apple trees. J. Amer. Soc. Hort. Sci. 107:198-202.
Williams, M.W. 1972. Induction of spur and flower bud formation in young apple trees with chemical growth retardants. J. Amer. Soc. Hort. Sci. 97:210-212.

Williams, M.W. 1973. Maturity changes and plant growth regulators. Proc. Wash. State Hort. Assn. 69:126-131. 